\title{
The Competition Between Thermal Contraction and Differentiation in the Stress History of the Moon
}

\author{
Randolph L. Kirk ${ }^{1}$ and David J. Stevenson \\ Division of Geological and Planetary Sciences, California Institute of Technolog.v, Pasadena
}

\begin{abstract}
The srarcity of looth extension and compression feal ures on the Moon strongly const.mins the

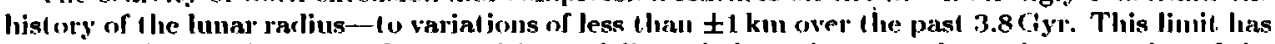
t raditionally beeu interpreted as recuuiring a delicate balaure het ween thermal cont rart ion of the near-surface and expansion of a substantial cold interior region. Recent theories of lumar origin (e.g., giant impact), in cont rast, favor a "hot" injtial state. We propose that a reconcilialion may le possible by laking account of the volume change $\Delta I /\left.V\right|_{d}$ die to diftrrentiation. We calculate S'TP tensit.jes based on sinuplified normat ive mineralogies fror a suile of est imales of the lulk lunal composition, of primary lumar basalt, and of the resillum left when the the uaximum anount of the lat ter is ext tacterl from the former. Typically $\Delta l /\left.l\right|_{d} \simeq 2$ to $5 \%$-an expansion equivalent. to healing by $\sim 10^{3} \mathrm{~K}$. Provirlerl the timing of differentiation is costret, one might uflset the cooting of a magma ncean as much as $630 \mathrm{~km}$ deep by differentiation of the remainder of the Moun (which need not slart much below the solidus temperature). A large but not impossiljle anumt of gablurnic melt. production is intlied: $\sim 100$ limes the volume of mate basalts known to have been extrurted. We do not address the retailed genetic relationship of this mell to the basialls observed on the lunar surface but. point out that it need not have reacherl the surface directly or even have entered the crust in order for the expansion to have orrurced. To assess the liming of melt formation, we investigate a simple conductive lunar tliermal model which takes account of bol.h $\Delta l /\left.V\right|_{d}$ and thermal cont tanclion. Our initial sl ate is characterized by a cent ral l cmperalure $T_{c}$ and a depth $Z_{0}$ above which the material (rletived (rom tlie magma ocean) is alrearly al the solirlus and is not suceptilile to volume changes upon further difTerentiation. We find a range of models satisfying the linuts on radius increase and decrease. The hottest has $T_{c}^{\prime}=12 \mid 0 \mathrm{~K}$,

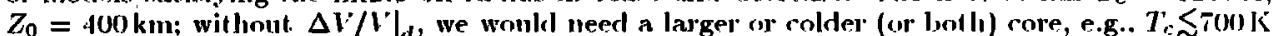
for $Z_{0}=200400 \mathrm{~km}$, in agreenent with previous investigators. Our inorlcling thus lenrls crerlence

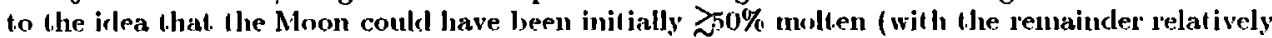
close to the solidus) and yet. experienced lit.le volume change over the last $3.8 \mathrm{Gyr}$.
\end{abstract}

\section{INTRODUC:TION}

Volumel.ric changes thronghout the interior of an evolving solicl planet. will inevitably be felt at the surface as stresses, potentially making themselves manifest. to the terrest rial observer througlt the creation of extensional or compressional teclonic features. T'hus the surface of Mercury betrays an eporlt of internal contraction, while that of Mars is inclicative of subatantial global expansion. 'The case of the Moon, on the otlier hand, is reminiscent of "the curious inciclent of the $\log$ in the night-1.ime" lamous in Holmesiana: the dog did nothing in the nigltt-time. Solomon and Chaikin [1976] demonstrated that the absence of tectonic featnres expected if the lunar radius had varied by by $\gtrsim 1 \mathrm{~km}$ [MacDonald, 1960] provides a strong constraint against which to tast modcls of the Moon's l.hermal listory. The limits on raclius variation per se apply only to the past $3.8 \mathrm{Gyr}$, since toctonic features from an earlier era may have been obliterated by the tail end of heavy impact hombardment. One may nonetheless nse them as a discriminant of theories of the formation of the Moon, to the extent that one is confident of knowing the physical processes by which that body evolves. Kuowing the differential equation, one sceks the initial conchition.

'Now al. Brauch of Astrogeology, U.S. Geological Survey, Flagstaf, Arizona

Copyright 1989 by the American Geophysical Union.

Paper number 88JR0:3213

0148-0227/89/88JB-3213 $\$ 05.00$
Solomon and Chaikin [1976] compuled the thermal volume cliange $\iint \alpha \partial T / \partial t d l^{*}$ dit for a suite of conduclive thermal models and found that if the radins constrainl is to be satisfied. the contraction of the ontermost layers of the Moon must be balanced by the radiogenic warming and expansion of a sulssianlial cold core. (Unless the contrary is clirectly iudicaled, we use the torm "core" in this paper to denote the inilially solid inner regions of the Moon of whatever composiliou, rather than the metallic iron region which is commonly meant.) Subsequent. work [Solomon, 1977; Solomon and Head, 1979] refined and substantiated this conclusion. A cold core comprising $60-80 \%$ of the volume of the Moon, with a cent.ral lemperature of no more than $\sim 70 n \mathrm{~K}$, would scrin to be required. 'These are distressing conclusions, in light of the current interest in models of lunar formation which lead to total or near-total melting.

Lixtensive melting of the Moon just after accretion becanse of short-lived radionuclides has been proposed by $R u n$ corn [197i]. Melling is also an expected concomilant of formation of the Moon by binary fission [ $O^{\circ}$ Keefe, 1969; W'ise, 1969; Binder, 1980]. The st.rongest stimulus to rencwed inlerest in a hot early Moon, however, lias been a class of theories of lunar origin involving the impact of a Mars-sized body on the Earth.h [Hartmann and Davis, 1975; Camron and W'ard, 1976]. Both morleling of a circmutcrrest.rial accretion disk formed by such an impact. ['Thompson and Stevenson, 1983; ('ameron, 1984; Stevenson, 1984, 1987; A. C. Thompson and D. J. Stevenson, Gravilational instability of lwo-phase disks and the origin of the Moon, submithed to Astrophysiral Journal, 1987] and numerical simulation of the impact process itself [Benz et al., 1986, 
1987] lead to the expectation that the source material for the Mloon inderwent complete melting. Because of the success (or at. least lack of clemonst rated fajlure) of the giant impart. models in explaining ot.her properties of the Moon, charification of their consequences for tectonic activity is of the greatest interest.

Hinder and Lange [1980] and Binder [1982, 1986] have claimed that the tectonic evidence on the Moon is consistent wit.l extensive early melting. In addition to const.ructing initially hot thermal evolution models which undergo less contraction than those of Solomon and Chaikin [1976] (bul. still $\gg 1 \mathrm{~km}$ ), they argued for a substantially st.ronger lunar lithosplicre. At the same time, they argued that compressional failure may actually be observed on l.he Moon both in the form of high-frerpency teleseisms (shallow monncuakes) and as the canse of highland scarps, and that stress may have been further relieved by undetectable slip on fanlts of the "Iunar grid." These clains lave been cliallenged [Solomon, 1986], and at best their validity is far from clear. The problem of the tectonic history of an initially molten Moon cannot be consiterfil solved.

()ur purpose in this paper is to point ont that existing at.1cmpts to apply the volumetric constraint to the Moon's early thermal history have been inadeguate in the plysics they conlain and hence possibly misleading. (Not knowing the proper dilletential equalion, one arrives al the wrong initial condition.) 'Thermal expansion is not the sole possible contribulor to evolutionary clanges in the lunar radius. The net cliange in volume accompanying melting, magma migralion, and refreezing, which has been neglected even in 1.hose studies which include melling in the energy balance, is potenlially as important.

This difrerentintion volume change is well known in the case of the Fartl. Oxbmigh and Parmentier [1977] calculatcol llac densitios of a mockel upper mantle, basallic ronst. and the depleted region produced by extracting the latiter from the former. Bol hasalt and depleted mantle were shown to be buoyant with respect. lo the undepleted mantle at the same temperat ure. The authors assumed a mass yield of basalt from undepleded mant.Je of $25 \%$, and obtained densities and layer thicknosses from which a net expansion of the cliflerentiated region of $4.55 \%$ may be calculated. The primary canse of this expansion is clear: npward migration of the uselt carries $\mathrm{Al}_{2} \mathrm{O}_{3}$ from the region of stability of garnet to that of plagioclase. The transformation proceeds in two stages. 'These are (for the magnesium end-menubr species):

$$
\begin{aligned}
\mathrm{Mg}_{3} \mathrm{Al}_{2} \mathrm{Si}_{3} \mathrm{O}_{12}+\mathrm{Mg}_{2} \mathrm{SiO}_{4} & \\
& \rightleftharpoons 4 \mathrm{MgSiO}_{3}+\mathrm{MgAl}_{2} \mathrm{O}_{4}
\end{aligned}
$$

and

$$
\begin{aligned}
\mathrm{CaMgSi}_{2} \mathrm{O}_{6}+2 \mathrm{MgSiO}_{3}+\mathrm{MgAl}_{2} \mathrm{O}_{4} \\
=\mathrm{CaAl}_{2} \mathrm{Si}_{2} \mathrm{O}_{8}+2 \mathrm{Mg}_{2} \mathrm{SiO}_{4}
\end{aligned}
$$

The fractional cliange in volume at stanclarcl temperalure ancl pressure for l.he first reartion is an extraordinary $26.6 \%$, ancl for the seconcl, $1.4 \%$. 'J'lie net. t.rans[ormation of garmet. 1.o plagioclase is accompanied by a $24.5 \%$ expansion (mineral densilics are takell from Basaltic Volcanism Study Project. (BVSP) [1!81]). Even when accomtt is taken of the lesser fraction of the whole rork which participates in the first. reaction, it. arcounts for ronghly nine-tenths of the tot.al volume cliange $\Delta V /\left.V\right|_{d}$ in lihe lunar case. The pressuretemperature-composilion pliase boundaries for these reaclions have been investigaled using both natural mincral mixtnres and idealizel synthelic systems [Green and Kingwood. 1967; Mac(iregor. 1964, 1965, 1970$]$. Al temperaI ures appropriate for early lunar history (cf. Figure 5), the plagiorlase-spinel transilion occurs at a deptlh of $180-200 \mathrm{~km}$ in the Moon $(P \simeq 1 \mathrm{Gl}$ a) and the spinel-garnet transilion a. $400-500 \mathrm{~km}(2.0-2.3(\mathrm{PPa})$ [BVSP, 1981].

Oxburgh and Parmentier [1977] also cited the pre[crential extraclion of iron from the depleted zone as a cause of the derrease in that region's densily. Examination of the excliange reactions

$$
\begin{aligned}
\mathrm{Fe}_{3} \mathrm{Al}_{2} \mathrm{Si}_{3} \mathrm{O}_{12}+ & 3 \mathrm{MgSiO}_{3} \\
& =\mathrm{Mg}_{3} \mathrm{Al}_{2} \mathrm{Si}_{3} \mathrm{O}_{12}+3 \mathrm{FeSiO}_{3}
\end{aligned}
$$

and

$$
\begin{aligned}
2 \mathrm{Fe}_{3} \mathrm{Al}_{2} \mathrm{Si}_{3} \mathrm{O}_{12} & +3 \mathrm{Mg}_{2} \mathrm{SiO}_{4} \\
& =2 \mathrm{Mg}_{3} \mathrm{Al}_{2} \mathrm{Si}_{3} \mathrm{O}_{12}+3 \mathrm{Fe}_{2} \mathrm{SiO}_{4}
\end{aligned}
$$

which have volume changes of $-8.7 \%$ and $1.2 \%$. respectively, shows l.hat migration of iron from the garnet to the plagioclase stability field prohably results in a small net contrartion when l.he two layers are considered logether. We are of course neglecting the effects of iron-magnesium ratio on compressibility, in which approximation lhe movemont. of fayalite and ferrosilite from intcrior to surface does not cliange the volume. In any case, the effect of $\mathrm{Al}_{2} \mathrm{O}_{3}$ migration is clearly the dominant one.

T'his mechanism of expansion will operate in the Moon as well as the Earth, provided differentialion transports stsceplible malerial upward ont of the garnet stability field. It. is also necessary that the downward flow (burial) of contuI ry rock required by conservation of mass does not recreate the lost garuet. (For the Earth, the former consicleration was of interest to Oxburgh and Parmentier [197i], but the latter was not. 'The differentiated material is recyclod into the mantle by subduction at the same rate at which it is created, and l.he Earth does not expand with time by this mechanism.) On the other hand. we emphasize that it is not necessary in order that there be a net expansion that the igneons product reach the surface of the hody or that il go to maks 11 , the conventionally clefined crust. There is no dired connection implied between the primary melt responsible for the expansion and the basalts encountered at 1.he lunar surface, with their various and complex fractionation lisstories. Once the aluminons material has reached the plagioclase (or spiucl) stability fickl, it may be reworked acl lilsitum withont appreciable additional change in volume.

We argue that the conditions for differentiation-driven expansion are (puile readily met. As the volume changes for like reaclions $(1 a)$ and $(1 b)$ slow, most of the expansion occurs at the garnet-spinel transition, at $4110-500 \mathrm{~km}$ depth. Basaltic melting below this depth is plausible [Ringwood, 1979] (sce also our modcls in section 4). The majority of the midt will almost certainly ascend to ahove this point, which is imnch deeper l.Jiant typically aclrocated skin deptlis even for the earliest stages of differentiation ['Toksöz and Solomon. 197.3]. As [or the return flow, this is likely to be composed primarily of the $\mathrm{Al}_{2} \mathrm{O}_{3}$-dcplcted material formed Irom the early magma ocean afier the fractionalion of the 
crust. W'e calculate below that. of the order of 0.1 luuar volume of melt will be produced, equivalent to a layer $\sim 65 \mathrm{~km}$ thick in the onler regions of the Moon. There is thus am-

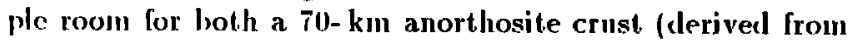
l.lic magma ocean) and a subsecuently formed gabbro laver within the plagioclase slability field. Of course, the int.rusive material is likely to solidify over a range of deptlis ratlier llan in a well-clefined layer. We nonetheless conclude, first, that previously formed crustal plagiorlase is not likely to be converted to spinel by burial and, second, that some of the gabbro may crystallize in the spinel field bnt its expansion will he nearly as great as if it had reached the plagioclase ficlel. Aluminous material is unlikely to enter the garnet ficld in any' ynanlity throngh burial. 'The volume effect of differentialion may thus be approximated by the conversion of garnetifcrous primordial mantle to residue plus plagioclasecontaining basalt.

The volume change for this process may be expected to diller from the corresponding expansion for terrestrial materials, becanse of compositional differences between the Earth and Moon. In section 2 of this paper we allempt to cuantify the amount of expansion caused by extracting basalt from undiflcrentiat.ed lunar material, laking acconnt of the uncertainly in our knowledge of the appropriate compositjons. The resulting estimate of $\Delta V /\left.V\right|_{d}$ is used in subseqnent. seclions to rompare the relative importance of thermal and diflerentiation cllects in the Moon's volumelric history. In section 3 we make some simple calculations, nol tied to any particular thermal evolution models, which show that differruliation is likely to be of major importance. section 4 presents a conductive thermal model and demonstrates the rrisults of including the differentiation volume change. Our discussion, section 5 , focmses on the possible relationship betwern our results and theories of lunar origin.

\section{('Al,CIIATION OF DENSITIFS}

Intorprotations of the composition of the lunar interior are fraught with a unmber of uncertainties, inclucling but scarculy limited to the current thermal state (whose calculation we seek here to advance). We therefore lake an inclusive, rallier thas exclusive, approach to the estimation of $\left.\Delta l \% l\right|_{d}$. We take from the literalure six widely differing bulk lunar composition modkels and t.wo suggesicd morlels for the primary basalic mell, ancl calculate the volume change on diflerentiation for all combinations. The range of results gives both estimales bounding $\Delta T /\left.V\right|_{d}$ within perhaps a factor of 2 and some understanding of the variables most. aflecling that cuantity.

'The sources of out composilional models are summarized in 'lable 1. OT the six bulk Moon models, numbered in order of decreasing $\mathrm{Al}_{2} \mathrm{O}_{3}$ and $\mathrm{CaO}$ content, two are from BVSI' [1981], section 4.5.2, and are "adjusted" versions of models by ol.hor authors. 'l'hat is, they have been derived from previonsly published models by varying a few paramelcrs (magncsium-iron ratio, core size, elc.) lo improve the agrecment between observed and model values of geophysical cuantities such as bulk density, monent of inertia, and seismic profiles. 'I'liree more moilds are among those consiclered in Hood and Jones [1987], while the sixth is from Buck and loksöz [1980]. 'I'wo potential models from the same sonress were nol used: BVSP [1981] model Mo3, which could not be adjusted salis[actorily, and Hood and Jones [1987] model 1, which cannot be projected onto the simpli-
TARLE 1. Soures of Compositional Morlels

\begin{tabular}{|c|c|}
\hline Mlorlel & Source \\
\hline MII & $\begin{array}{l}B \text { BVP [1981] morlel Mo1, adjust ed } \\
\text { from Morgan et. al. [1978] }\end{array}$ \\
\hline M2 & $\begin{array}{l}\text { Hood and Jones [1987] nodel } 1 \text {, } \\
\text { from Tay/or [1982] }\end{array}$ \\
\hline Mt3 & $\begin{array}{l}\text { BVSP [1981] model Mo2, arljusted } \\
\text { from Wïnke ct al. [197T] }\end{array}$ \\
\hline MII & Buck and Toksöz [1980] \\
\hline M15 & $\begin{array}{l}\text { llood and Jones [1987] model } 3 \text {, } \\
\text { from Wänke et al. [1977] }\end{array}$ \\
\hline $\mathbf{M 6}$ & $\begin{array}{l}\text { Hood and Jones }[1987] \text { moclel } 4, \\
\text { Trom Delano }[1984]\end{array}$ \\
\hline Bt & $\begin{array}{c}\text { A pollo } 12 \text { alivine basalt } 12009 \text { plus } \\
10 \% \text { log }\end{array}$ \\
\hline B2 & $\begin{array}{l}\text { Apollo } 15 \text { gipen glass [ Gireen and } \\
\text { Ringwood, 1973] }\end{array}$ \\
\hline
\end{tabular}

fied mineralogical scheme we use (see below). The models from BVSP [1981] and Buck and Toksöz [1980] have the advantage of having been fit, to selenophysical constraints and seismic velocity estimales. The seismic profiles used [Goins, 1978] differ substantially, however, from those of Nakamura [ 1983] based on a more complete mooncuuake clat.aset. Hood and Jones [1987] tested their models (withont adjust.ment) against the latler under a variety of assumptions about the l.hermal and differcutiation state of the Moon. We will discuss their conclusions below.

Our basalt molels are the compositions of two lunas: samples thonght to be candidates for a primary basaltic melt: the Apollo 12 olivine basalt. 12009 modified by the aclililion of $10 \%$ olivine of composition Fo 5 [Green et al., 1971], and the Apollo 15 cmerald green glass [Green and Ringwood, 1973]. We also carricel out calculations for a number of Apollo 15 low-titanium lasalts bul do not tabulate the results, which were generally similar to those for moklels $\mathrm{B} 1$ a.til [32.

Hecognizing the nnavoidable uncertainties due to the range of composition modrels available, we simplificel as far as possible the method by which the volmme cflect. of diflerenliation was estimated. For each combination of bulk Moon ancl basalt. models, llif maximum mass fraction of basalt ex1 ractable from the primordial malerial was calculated. The densilies al standard temperature and pressure of the primorlial mantle, the basalt, and the residnum after complete melt exiraction were thell compared to give an estimate of $\Delta V /\left.I^{\circ}\right|_{\text {a }}$. 'The neglect of compressibility effects implicit in this uncthod is justified by the relatively low pressures in the lunar interior as well as by our desire for a simple, robust. result.

More important. the yickls and $\mathrm{S}^{\prime} \Gamma \mathrm{P}$ clensilies were themselves calculatcl usiug a simplified mineralogical scheme. We chose to deal with only the oxjeles $\mathrm{SiO}_{2}, \mathrm{Al}_{2} \mathrm{O}_{3}, \mathrm{MgO}$, FeO, and CaO. Minor clements being more susceptible to secondacy processes of enrichment aud depletion, their inclusion in l.te calculation of primary basalt yield $X_{\text {max }}$ coulel be misleading. From the published analyses we therefore removed $\mathrm{TiO}_{2}$ (as ilmenite), $\mathrm{Cr}_{2} \mathrm{O}_{3}$ (as chromite), $\mathrm{MnO}$ (as rhodonit.c), $\mathrm{Na}_{2} \mathrm{O}$ (as jadeite at high pressure, as albite a.t low pressure), and $\mathrm{k}_{2} \mathrm{O}$ (as orthoclase) and renormalized the remaining oxides to $100 \%$. The resulting simplified analyses (it percent. hy mass) appear in 'lable 2; for the original analyses the reader is directed to the literature. Removing 
TABI,F, 2. Compositions and Densil ies of Moon, Basalt, and Residuum Models

\begin{tabular}{|c|c|c|c|c|c|}
\hline & MI & M2 & M3 & $\mathrm{M} 4$ & M5 \\
\hline $\mathrm{SiO}_{2}$ & 40.351 & 44.207 & 48.096 & 49.020 & 44.830 \\
\hline $\mathrm{Nl}_{2}\left(\mathrm{O}_{3}\right.$ & 7.515 & 6.023 & 4.895 & .8 .846 & 4.415 \\
\hline $\mathrm{MgO}$ & 25.860 & 34.732 & 30.229 & 29.588 & $34.42 y$ \\
\hline lies & 11.038 & 10.406 & 12.647 & 12.641 & 12.536 \\
\hline ('aO) & 6.235 & 4.632 & 4.132 & 3.906 & $3.7(31$ \\
\hline$\Sigma$ & 99.999 & 100.000 & 99.949 & 100.001 & 100.001 \\
\hline \multicolumn{6}{|l|}{$\Lambda n$} \\
\hline ()) & 6.523 & 45.909 & 23.466 & 17.309 & 45.828 \\
\hline Opx & $3 \pi .197$ & 10.774 & 39.686 & 44.399 & 20.778 \\
\hline $\mathrm{Di}$ & 24.423 & 18.116 & 16.182 & 18.626 & 14.728 \\
\hline $\mathrm{Ga}$ & 31.857 & 25.171 & 20.667 & 19.636 & 18.6146 \\
\hline$\Sigma$ & 100.000 & 100.000 & 100.001 & 100.000 & 100.000 \\
\hline \multirow{3}{*}{$\begin{array}{c}\operatorname{Mg}^{\prime} \\
\rho \operatorname{sir} \Gamma, \mathrm{kg} \mathrm{m}^{-3} \\
\end{array}$} & 0.7954 & 0.8170 & 0.7986 & 0.7952 & 0.8200 \\
\hline & 3468.5 & 3443.9 & 3437.1 & 3434.4 & 3445.3 \\
\hline & M6 & B1 & B2 & $\mathrm{M1}$ - B1 & $\mathrm{M} 11-\mathrm{B} 2$ \\
\hline $\mathrm{SiO})_{2}$ & 41.315 & 46.796 & 41.828 & 52.560 & 52.174 \\
\hline $\mathrm{Al}_{2}()_{3}$ & 3.519 & 8.106 & 7.838 & 6.7 .4 & 7.315 \\
\hline$M \lg ()$ & 36.286 & 15.809 & 17.321 & 38.372 & 31.191 \\
\hline Fro & 16.0635 & 19.826 & 21.300 & & 4.632 \\
\hline $\mathrm{CaO}$ & 2.815 & 9.373 & 8.713 & 2.294 & \\
\hline$\Sigma$ & 100.000 & 100.000 & 100.000 & 100.000 & 100.000 \\
\hline$A_{\mathbf{n}}$ & & 22.058 & 21.387 & & \\
\hline () & 67.587 & 19.360 & 31.789 & 7.665 & \\
\hline()$_{p x}$ & 6.531 & 39.398 & 29.589 & 55.973 & 51.525 \\
\hline $\mathrm{j}) \mathrm{i}$ & 11.023 & 19.185 & 17.235 & 8.983 & 18.359 \\
\hline (ia & 14.859 & & & 27.379 & 30.116 \\
\hline$\Sigma$ & 100.000 & 100.001 & 100.100 & 100.000 & 100.000 \\
\hline \multirow{3}{*}{$\begin{array}{c}\mathrm{Mg}^{\prime} \\
\Gamma S T F, \mathrm{~kg} \mathrm{~m}^{-3}\end{array}$} & 0.7894 & 0.5709 & 0.5743 & 1.0000 & 0.0178 \\
\hline & $3+181.1$ & 3338.8 & 3365.8 & $329: 3.6$ & 3370.6 \\
\hline & $\mathrm{M} 2-\mathrm{B} 1$ & $\mathrm{M} 2-\mathrm{B} 2$ & $\mathrm{M} 3-\mathrm{B} 1$ & $\mathrm{M} 3-\mathrm{B} 2$ & $\mathrm{~N} 4 \mathrm{1}-\mathrm{B} 1$ \\
\hline $\mathrm{SiO}_{2}$ & 41.675 & $4: 3.31: 3$ & $4 ! 1.121$ & 51.044 & 50.809 \\
\hline $\mathrm{Al}_{2} \mathrm{O}_{3}$ & 3.488 & 4.200 & 2.304 & 2.241 & 2.518 \\
\hline$M \lg ()$ & $5.3 .1: 3$ & 51.362 & 41.528 & 41.873 & 39.366 \\
\hline licos & 1.201 & & 6.988 & 4.842 & 7.508 \\
\hline$\left(\mathrm{C}_{\mathrm{n}} \mathrm{O}\right.$ & & 0.735 & & & \\
\hline 5 & 100.000 & 100.000 & 100.001 & 100.000 & 100.001 \\
\hline \multicolumn{6}{|l|}{$\Lambda_{n}$} \\
\hline () & 81.116 & (69).4:32 & 36.275 & 27.799 & 26.1333 \\
\hline()$_{p x}$ & 2.720 & 10.350 & 53.905 & 63.025 & 63.480 \\
\hline $13 i$ & & 2.876 & & & \\
\hline Gia & 16.164 & 17.342 & 9.731 & 9.176 & 10.387 \\
\hline$s$ & 100.000 & 100.000 & 100.0101 & 100.000 & 100.0000 \\
\hline \multirow{3}{*}{$\begin{array}{c}\mathrm{Mg}^{\prime} \\
\rho_{S T F}, \mathrm{~kg} \mathrm{~m}^{-3}\end{array}$} & 0.98136 & 1.0000 & 0.9079 & 0.9348 & 0.8969 \\
\hline & 3287.9 & 3282.3 & $333: 3.2$ & 3294.8 & 3.328 .5 \\
\hline & $\mathrm{A}+4-\mathrm{B} 2$ & $\mathrm{M} 5-\mathrm{B} 1$ & $\mathrm{M} 5-\mathrm{B} 2$ & $\mathrm{M} 13-\mathrm{B} 1$ & $\mathrm{M} 6-\mathrm{B} 2$ \\
\hline $\mathrm{Si}()_{2}$ & 52.425 & 43.512 & $44.8: 34$ & 38.964 & 39.639 \\
\hline $\mathrm{AI}_{2}\left(\mathrm{O}_{3}\right.$ & 2.415 & 1.902 & 1.868 & 1.550 & 1.458 \\
\hline $\mathrm{MgO}$ & 39.554 & $4 \pi .847$ & 47.417 & 45.0 .36 & 45.335 \\
\hline $\mathrm{FeO}$ & 5.605 & 7.650 & 5.880 & 14.450 & 13.567 \\
\hline \multicolumn{6}{|l|}{$\mathrm{CaO}$} \\
\hline$\Sigma$ & 99.999 & 100.001 & 99.999 & 100.000 & 99.999 \\
\hline \multicolumn{6}{|l|}{$A_{n}$} \\
\hline ()) & 17.977 & 70.459 & 61.889 & 92.423 & 89.529 \\
\hline$O_{p x}$ & 72.105 & 21.346 & 27,452 & 1.109 & 4.396 \\
\hline \multicolumn{6}{|l|}{$\mathrm{Di}$} \\
\hline Ga & 10.387 & 8.195 & 7.660 & 6.4138 & 6.075 \\
\hline$\Sigma$ & 100.000 & 100.000 & 100.001 & 100.000 & 100.000 \\
\hline $\mathrm{Mg}^{\prime}$ & 0.9213 & 0.9104 & 0.9305 & 0.8379 & $0.8+72$ \\
\hline pSTP, $\mathrm{kg} \mathrm{m}^{-3}$ & 3301.0 & 3337.6 & 3311.6 & 3.128 .6 & 3114.0 \\
\hline
\end{tabular}

All composilions in weight percent. An, anorthite; Ol, olivine: $O_{p x}$ orthopyroxeme; Di, diopsirle; Ga, pyorop-almantine garnet; $:$, tolal. $\mathrm{Mg}^{\prime} \equiv \mathrm{MgO} /(\mathrm{MgO}+\mathrm{FeO})$ by mole. 
1.ho minor minerals, which are largely "inert" (i.e., which refreez: in their original pliases) during the differentiation process, from the composilion will result. in a small overestimate of $\Delta V /\left.F\right|_{\text {a }}$. Since they comprise only alont $1-3 \%$ of the mantle. this cffect is much smaller than the variability hetween diflerent compositional models.

We furlicer simplify our analysis by neglecling the solid solution of $\mathrm{Al}$ in pyroxenc, by considering pyrope-almandite garmols hut nol grossular, and by assmming [Oxbugh and l'armentier. 1977] that the magnesium-iron ratio is the same in olivine, orthopyroxene, and garnet. but that no iron is incorporated in clinopyroxene. Onr chemical analyses can then be interpreted uniquely in terms of the mincral assemblages olivine-orthopyroxene-diopside-garnet at high pressure and nnorthitc-olivine-orthopyroxene-diopside at low pressure ('Table 2). We do not consider the spinel stability field. As indicated in the introduction, the conversion of garnet lo spinel results in much greater expansion than the conversion of spinel to plagioclase. The calculated value of $\Delta V /\left.\left.\right|^{\circ}\right|_{t}$ would thus be approximately correct even if the mell were to frceze in the spinel field. Furthermore, this region is occupical in the cases of most interest 1.0 us by alumina-poor malcrial solidificd [rom the primordial magma orean, which wonld undergo lit.1le volume change upon furl. locr differentiation.

The efuilibria for formation of the neglected aluminous phases are pressurc and temperature dependent and somewhal uncerlaiu [dkella, 1976; Perkius ef al., 1981]. Their incorporation into onr rough, global estimate of $\Delta V /\left.I^{\circ}\right|_{d}$ would t.lus be diflicult. Al any rate, aluminous pyroxcenes may comprise $46 \%$ of the lunar mante [BVSP. 1981]. 'Their reaction with orthopyroxene in a $2: 1$ ralio to lorm garnet. (effertively forced by our simplified scheme) resnlts in a contraction amounting to $\sim 7 \%$ of the volume of the reartants. 'I'le' net ellect of neglecting them is thus of the order of $1 \%$ in the calculation of S'IP ,lensities [cf. Buck and Toksöz, 1!80]. Because we neglect the aluminous pyroxenes both before and after diflerentiation, partial cancellation will cause llie effect on $\left.\Delta l \%\right|_{d}$ to he smaller. 'The eflect on ST'P de'tsity of converting grossular to pyrope-almandite, evaluated in a similar way, is only $\sim 0.105 \%$.

We nole in passing, however, that onr simplified analysis results in a negative normative orthopyroxene content for Hood and Jones [1987] modcl 1, which was therefore not ustel in this stmely. Consideration of a more complete projertion scheme wonld climinate this anomaly.

In addition to the simplified oxicle and mineral analyses, 'Table 2 gives the whole rock value of $\mathrm{Mg}^{\prime} \equiv \mathrm{MgO} /(\mathrm{MgO}+$ Fe() by mole, and the calculated density at standard temperature and pressure. Densilies of mineral species were based on values for magnesium and iron end-members talunlalod in BVSP [1981], interpolated linearly for intermediate compositions.

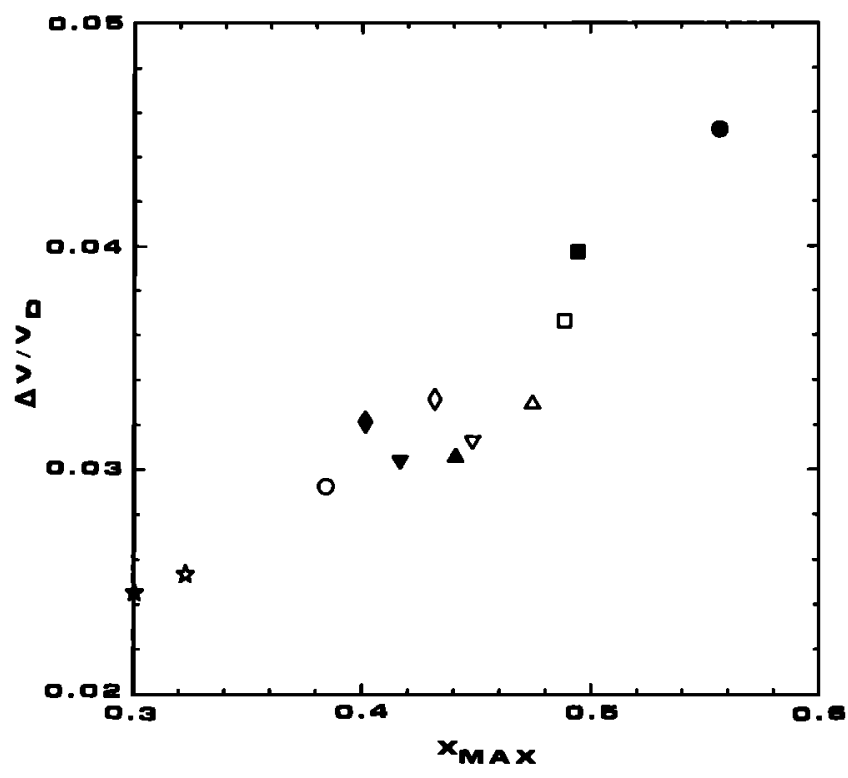

Fig. 1. Volume rlange on differentinl ion versus naximum mass

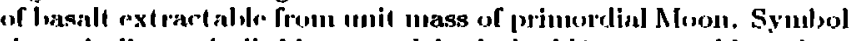
shape inclirates loulk Mron! norlel: rirrle. N1; sepuare, M2; triangle, N13; invertol i riangle, MA; diamond, M5; star, M6. Symbol sliarling indlical es basali model: solid, B1; open, B2. See Table 1 for sources of morlels.

For each combination of bulk Moon and bassall. composition. we next calculate the maximum amount of the latl.ev which can be extracted from the former. 'The yield is usmally limited ly the exhanstion of one of the constituent. oxides in llic residue. In some cases, however. a composilion corresponding to the vanishing of one of the normative minerals is achieved first. Included in Table 2 are the composilions of the limiting-case residues and of course their derusitics. (That the residnes are generally less dense than thr basalt is perliaps supprising, lnut cloes not preclucle "1pward differentiation, since the basaltic melt, will be buoyant. wills $\rho \simeq 3000 \mathrm{~kg} \mathrm{~m}^{-3}$ [Boltinga and Weill, 1970].) T'he volume change $\Delta V /\left.V\right|_{d}$ for complete hasalt extraction is given for earli pair of compositions in 'lable 3 , along with the maxinmun yicel (as a ratio by mass) and the element or mineral whose almmdance is limiting. The results are also summarized in Figure 1.

As expected. our estimates of the differentiation volume change vary hint are all in the range of a few percent. It is clear from Figure I that. l.he primary factor determining $\Delta V /\left.f\right|_{d}$ is the fraclion $F_{\max }$ of the primordial rock which can be converled to basalt. Since the yiclel is in most cases limited by $\mathrm{CaO}$, there is an accompanying trencl towarl larger values of $\Delta V /\left.V\right|_{d}$ for bulk Moon models which are richer in $\mathrm{CaO}$ and $\mathrm{Al}_{2} \mathrm{O}_{3}$ four lower-nnmbered models). Other influences are more subtle, but one' at least.

'TABLE 3. $\Delta F /\left.V^{\prime}\right|_{l} X_{\max }$, and Limil ing Element/Mineral

\begin{tabular}{|c|c|c|c|c|c|c|}
\hline & MII & $\mathrm{M} 2$ & M3 & M.1 & M5 & M6 \\
\hline \multirow[t]{2}{*}{$B 1$} & $0.0-152$ & 0.0396 & 0.0 .3044 & 0.0305 & 0.0321 & 0.0245 \\
\hline & $\begin{array}{c}0.5567 \\
\text { lie }\end{array}$ & $\begin{array}{c}0.49 .42 \\
C_{a}\end{array}$ & $\underset{C .1 .108}{0.9}$ & $\begin{array}{c}0.1165 \\
\mathrm{Ca}_{a}\end{array}$ & $\begin{array}{c}0.1013 \\
\mathrm{C} ! \mathrm{a}\end{array}$ & $\begin{array}{c}0.3003 \\
C_{\mathrm{a}}\end{array}$ \\
\hline \multirow[t]{2}{*}{$B 2$} & 0.0292 & 0.03365 & 0.0328 & 0.0311 & 0.0331 & 0.0253 \\
\hline & $\begin{array}{c}0.38-1.3 \\
\text { ()] }\end{array}$ & $\begin{array}{c}0.4885 \\
\text { Fe }\end{array}$ & $\begin{array}{c}0.17 .13 \\
C_{3}\end{array}$ & $\begin{array}{c}0.1481 \\
C_{a}\end{array}$ & $\begin{array}{c}0.1316 \\
\mathrm{Ca}\end{array}$ & $\begin{array}{c}0.3230 \\
C^{\prime} a\end{array}$ \\
\hline
\end{tabular}


may be remarked: basalt $\mathrm{B} 2$, which is richer in $\mathrm{FeO}$ and $\mathrm{MgO}$, poorer in $\mathrm{SiO}_{2}$ aud $\mathrm{CaO}$ l.han $\mathrm{Bl}$, has higher $\mathrm{I}_{\text {max }}$ and $\Delta l / \mid l_{d}$ willh the calcium-aluminum-poor Moon models. When paircel with M1 and $M 2$, howeves, it is limited respectively by olivine (i.e., too much $\mathrm{SiO}_{2}$ left in the residuc) and iron, and lower values of $\Delta V /\left.V^{\prime}\right|_{\text {d }}$ result. Iı light of l.hese tronds, it is interesting that Hood and Jones [1987] report the greatest. success in fitting seismic velocity constraints for their most aluminous bulk models: onr MI2 and the "muadjusted" precursor of M1. This is in parl a consequence of the increase of seismic velocities in the lower mantle calculatcl by Nakamura [1983], favoring the presence of garnet. The earlice velocily profiles of Goins [1978] showed a drop

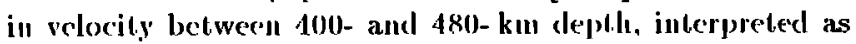
a consequince of the presence of Fe-FeS [Buck and 'loksöz, 1980; [3VSP, 1981] or less likely, a clecrease in $\mathrm{Mg}^{\prime}$. Valnes of $\Delta V / V$, lowards the upper end of our range would thins seem to be lavored, mnless the primary moll was especially iron-magnesium rich. We will nevertheless adopt the more conservative values $\Delta V /\left.V\right|_{d}=0.03, X_{\max }=0.4 \mathrm{in}$ our exploration of the importance of differentiation in the remainder of this paper.

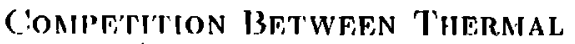 AND C'OMYOSIIIONAL EFFECTS}

The nel. expansion resulting from dillerentiation of lunar malerial is so large that it is likely to be an important lactor in Ihe volume history of the Moon unless formation involved eiller complete melling or such low tcmperatures that the solidus was never thereafter achieverl. The typical $3 \%$ expansion arriver at above corresponds, for example, to the effect of heating olivine from 425 1.0 $1350 \mathrm{~K}$ [Skinner, 1962]. T'le npper limits on the contributions to expansion of the lunar interior from warming and from basalt formation are t.lus mearly equal. In hisis seclion we will attempt to eslimale lic minimum amomul of difterentiation recuired to ollsed the expected thermal contraction of the onter layers of the Moon. In this way we may place a rough limit on the "loottest." initial stale consistent with a nearly constant lunar volume, subject to the minimum number of cuestionable assmuplions.

The lleermal contraction of a hot Moon is largely inclependent of the derails of hoat transport in the interior, since it is dominaled by the thickening of a cold boundary layer near the surlace. Deilailed moclels of Ihe lunar magma ocean [e.g., Solomon and longhi. 1975] indicate that lhe ont.cr regions of the Moon will have largely' or cullitely frozen by 3.8 Gyj ago. 'J'lic boumdary layer may ilierefore le modeled as a 11 niform, concluctively cooling solicl. We adopt a thermal diffusivily $\kappa=7.5 \times 10^{-7} \mathrm{~m}^{2} \mathrm{~s}^{-1}$ [Toksöz and Solomon, 197:3] and a coeflicient of themal expansion $n=4 \times 10^{-5} \mathrm{~K}^{-1}$ [Solomon and (haikin, 19i6] as representalive for a range of lemperatures. In 3.8 (iyr the thermal boundary layer will have achieved a thickuess of the order of $\sqrt{\kappa i} \simeq 300 \mathrm{~km}$. This is sufliciently thin compared with the radius of the Moon hat we can ignore the ellects of spleerical geometry to a reasonable first approximation. (]n fact, the effects of our simple assumptions aboul the boundary layer geometry and 1he t.emperalure-independent thermal expansion coefficient largely cancol, resulting in a fortuitously good agreement. willt the results of the more detailed model presented in the ncexl section.) (Convection, if present, does not greally mod- ily this estimnte [C'assen ef al. 1979; Schubert el al., 1980]. Across this laycr the temperature varies from the solidus, $\sim 1350 \mathrm{~K}$, to the equilibrium surface temperature, $\sim 250 \mathrm{~K}$ [Toksöz and Solomon, 1973], giving an average cooling of $\sim 550 \mathrm{k}$. 'The resulling change in the raslins of the Mloon is roughly $\sim 5.5 \mathrm{~km}$. 'T'his is comparable to the net contraclion for the holtest thermial models of Solomon and ('haikin [1976], which do not, of conrse, include differentiation.

In order to yield a nct raclius cliange of less than $1 \mathrm{~km}, \mathrm{l}$ his thermal contraction must be oftset by $4.5 \mathrm{~km}$ of expansion lue to differentiation (we ignore warming of the interior). Using $\Delta l /\left.l\right|_{d} \simeq 0.03$, we see that $\sim 26 \%$ of the volume of the Mloon) expivalent to a sphere $1110 \mathrm{~km}$ in cliameler) minst be completely difterentiated. If $n$ is allowed to be as low as $2 \times 10^{-7} \mathrm{k}^{-1}$, h.his value clecreases $1.0810 \mathrm{~km}(10 \%$ of the Moon's volume). Allowing the core to start out cold will Iurther clecrease ils recuired size 10 as lit.le as $680 \mathrm{~km}$, a fact of intercst if one seeks the Moon model with the grealest degrce of initial melling, rather than the most uniformly high temperature. Ilypothetically. then, the radius constraint may be salisfied whilc permitting hy far the majorily of the Moon's mass to be molten al lie lime of formation.

How muclt basaltic melt is produced by the difterentiation of a $1110-\mathrm{km}$ Inuar core? According to the results of secfion 2, a tolal of $\sim 0.4 \mathrm{~m}^{3}$ of basalt may be extracted from I $\mathrm{mi}^{3}$ of primordial Imur material. Approximately $10 \%$ of the lunar volume of melt is thus produced. most of which must refreege bofore reaching the surface. 'l'he total volume of mare basalt eruptod onlo lle surface has beell estimated at $\sim 1 \%$ of the volume of the crust, or $\sim 0.1 \%$ of the litllar volume [Head. 1975]. The ratio of mell production to extrusion is this of the order of $100: 1$. The complexity and variely of diffrentiation patterns in the observed lunar hasalts argue for remelting and reworking of the primary gahbro, so that the ralio of inl.rusive to extrusive activity is probably somewhat greater. 'Though large, this ratio cannot. be excluded on the basis of any pliysical arguments (see ser:tion 5).

Disposition of $10 \%$ of the lunar volume of gabliroic matcrial in the ontcr regions of the Moon is not necessarily inconsistent with the olsserved scismuic velocity profile [Nakamura, 198:3]. We have calculated approximate seismir velocilies for our morlet basalts in the plagioclase and spincl stability ficlds, based on the mineral elastic propert.jes labulated by Hood and Jone's [1!87], our whole rock velocities being volume averages of those for the indiviclinal mincrals. We concentrate on the shear wave velocity $V_{e}$, on which the observalional const raints are stronger. In the spinel ficld, $V$, ranges from $\sim 4.27 \mathrm{~km} \mathrm{~s}^{-1}$ at 201$)-\mathrm{km}$ depth to $\sim 4.15 \mathrm{kms} \mathrm{s}^{-1}$ at. $5011 \mathrm{~km}$. Nakamura s [1983] estimate $V_{s} \simeq 4.25 \pm 0.1 \mathrm{~km} \mathrm{~s}^{-1}$ is thus consistent even with a pure gabloro layer al this clept.h. In the plagioclase field, Nakamura's velocily is higher $\left(4.49 \pm 0.03 \mathrm{~km} \mathrm{~s}^{-1}\right)$ and that for l.lie gabloro is lower $\left(4.23-4.106 \mathrm{~km} \mathrm{~s}^{-1}\right)$. Models of this region as the source from which the crust was derived ty y) cally liave $r$ in excess of observalion, however, at least near (he surlace [Hood and Jones, 1987]. 'T'he dala lins admit of a sulsstantial admixt.ure of gabbro into the magma-ocean resiclue, more than sufficienl to accommodate the amoumt of melt covisioned liere. 'These argmments are far from conClusive, lul seismic velocity measurements do not seem to rule ont the emplacement of a substantial culuantity of gabbro above $500-\mathrm{km}$ dcpth in the Moon. 


\section{IMIPLICATIONS FOR LUNAR JIISTORY}

The calculations of the previons section inclicate that differentiation of a small fraction of the lunar inlection could oflset substantial themmal conl.raction. 'T'hey do not guarantlee that a balance leacling to radius variations of Jess than $\pm 1 \mathrm{~km}$ in the last 3.8 (iyr can actually be attained. Such a balance would drpend on the liming of differentiation and thermal contraction and at best would likely be imperfect, satisfying the radius constraint but resulting in more than the minimum amonul of differentialion over time. (For example, any hasalt formation before 3.8 Gyr ago is "wasted.") Inlortunalely, the intial condilions (if any) which will lead to an acceptable radius history can only be determined in the context of specific assumptions abont the thermal evolution of the Mloon. Onr purpose in this section is not to formulate the definitive model of the Moon's thermal and dillerentiation history. Rather, we are content to show that lloc incorporation of $\Delta V / l / l_{d}$ in a simple thermal model results in acceplable radius variations lor substantially "hotter" initial states than wonld otherwise be possible.

We have chosen to consider a conductive thermal evolution model. similar in many respects to that described by Toksöz and Solomon [1973], and employed also in Solomon and ('haikin [1976] and Solomon [197T]. It might, seem strange to pursuc a conduclive model, in view of the almost. Iniversal accoptance of sulsoliclus convertion as the primary moans of eliminating heat from homogeneons terrestrial bodies, even those as small as the Moon [rf. Tozer. 1972; Sr hubert of al., 197i]. We have chosen this approach for the following reasons. (1) We wish to compare ont results with the only previous well-documented nodels of radius change, and those modcls are conductive. (2) Plausible models for the early Moon may involve a prolonged conductive phasc for the cleep interior if the core is colcler than lhe npper layers. (3) There is no generally accepted scheme or recipe for modeling convection conpled to differentiation. (1) We dispute the conventional wisclom that subsolidus convection is an incritable event ual state for the (leep interior of the Moon, in light of the possilility that sulsstantial com- positional gradients may arise during irreversible differentiation. (5) Some of the results may be insensitive to the details of the licat transport mechanism (a point discussed further at the end of (his section).

We ellploy the same explicit finite difference scheme as Solomon and coworkers to solve the themal conduction equation in spherical coordinales,

$$
\rho C_{r} \frac{\partial T}{\partial t}=\frac{1}{r^{2}} \frac{\partial}{\partial r}\left(r^{2} k \cdot(r, T) \frac{\partial T}{\partial r}\right)+H(r, t)
$$

whore $\rho$ is donsity, $C_{p}^{\prime}$ is specific heat, and $H$ is the contribution of heal sources. We adopt a number of the same valnes of plysical parameters ('Table 4) as the above anthors. We also characterize our initial state by the same cuantities: a central temperatnre $T_{c}$ and a clepth $Z_{0}$. Above $Z_{0}$ 1.he initial tempcrature follows the solidus, while below it varif's cuadratically with depth hetween the soliclus and $T_{c}$. Our model uses a simplificel hasalt solidus. however, which varics qualratically wil.h depth (linearly with pressure) from $1348 \mathrm{k}$ at the surface to $1883 \mathrm{~K}$ at the center of the Moon [Solomon and Toksöz, 197:3]. In actlition, we adopt. 1/, lower crustal l.hermal conduclivity of Binder and Lange [1981].

Wilhere our model necessarily departs from loksöz and Solomon [197:3] is in the trealment of me]ling. Only the originally undifferentiated region below $Z_{0}$ is permitted to mali. ('l'he ontcr layers, once solidified from the unagma orean. never become hot enough for remelting to occur.) 'The puantily of moll $X$ previously extracted from the malerial al earl deptl is maintained as part of the calculation; it is initially zero. (icnerally, $\partial T / \partial t$ is determined from (3), and $\partial . \mathcal{X} / \partial t=0$. If, however, the temperature is at the solidlus, the righlland sicle of $(3)$ is positive, and $X$ is less than $X_{\max }=0.4$ (section 2), then $\partial T / \partial t=0$, and melting occurs according to

$$
\rho L \frac{\partial X}{\partial t}=\frac{1}{r^{2}} \frac{\partial}{\partial r}\left(r^{2} k(r, T) \frac{\partial T}{\partial r}\right)+H(r, t)
$$

We adopl a latent lreal of fusion $L=4 \times 10^{5} . \mathrm{kg}^{-1}$ [Binder

\begin{tabular}{|c|c|}
\hline rarameler & Value \\
\hline 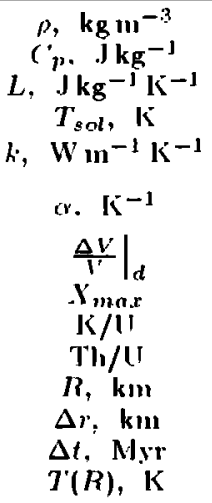 & $\begin{array}{l}3340^{a} \\
1200^{a} \\
4 \times 10^{5} a \\
1348+0.113 I^{b} \\
\frac{418.1}{30.6+0.21 T}+\max \left[0,2.3 \times 10^{-3}(T-500)\right]^{c, d} \\
\frac{2.2 \times 10^{-5}-1.05 T^{-2}+1.44 \times 10^{-8} T}{1+2.2 \times 10^{-5} T+1.05 T^{-1}+7.2 \times 10^{-9} T^{2}} \\
0.03 \\
0.4 \\
2000^{a} \\
3.7^{f} \\
1740 \\
20 \\
2 \\
253^{g}\end{array}$ \\
\hline
\end{tabular}

TABI,F 4. Parameters for Thermal Evolution Mlodels

a Toksöz and Solomon [107:3].

c 'f'jü MPa.

d Schitz and Simmons [1972] in mantle. Vahues 2.1), 0.5 [rom Rinder

and Lange [1580] used in crust. (20-80 km) and regulith (0-20 km).

- Skimer [1!1;2] for olivine.

i Solomon [197-7].

9 Langseth et al. [1!72]. 
and Lange, 1980]. 'The melt is assumed to migrale upward instantanconsly and refreeze in the crust (depths less than $80 \mathrm{~km}$ ), depositing its latent, heat. This must be understond as purcly a matter of convenience in "bookkeeping" for the cnergy bulget; we do not mean 1.0 imply that the $80-\mathrm{km}$ linar crust was formed from the relatively late-forming melt that charactcrizes our model. Rarliogenic heat sources are also assumed to partition culirely int.o the melt., such that by the time $X=X_{\max }$, their concentration in the residue vanishes. Both latent lieal. and radionuclides are deposited in proportions varying exponentially with depth in the crust; a skin depth of $30 \mathrm{~km}$ is assumed hnt has little impact on the resulis. We do not inclucle in our model the inward transport of heat ancl mass which is implied hy the shrinkage of the residunu as molt is exl.racted. Nor do we altempt. to describe the higher-tremperature melting which would occur after basalt extraclion is complete, since we find thal $X=$ $\mathrm{X}_{\text {mas }}$ is not rearlied in our morlels.

T'le radius hislory of the Moon is evaluated by integrating over time the expression

$$
\frac{\partial \Delta R}{\partial t}=\frac{1}{R^{2}} \int_{0}^{R}\left(\alpha(T) \frac{\partial T}{\partial t}+\left.\frac{\Delta V}{V}\right|_{d} \frac{1}{\bar{X}_{\max }} \frac{\partial . Y}{\partial t}\right) r^{2} d r
$$

which inclucles both thermal and differentiation effects in an approximate way. The initial condition is chosen a posteriori such that $\Delta R=0$ at the present. day. It is sufficieut to use the presentl-day value of the lunar radius $R$ on the right-hand side of this equalion.

We evaluate the success of our thermal histories against several constraints. 'The most important is that on lithospheric sl.ress resulting from changes in radius. A brief comment on the relationship between st ress and radius in a difforentialing hooly is in order. 'The $\pm 1 \mathrm{~km}$ limit on radius cliange is clerived from a limil of roughly \pm 1 kbar on the tingrntial st ress $\sigma_{t}$ sustainable by the lithosphere without fracture, and the relationship)

$$
\sigma_{\mathrm{t}}(R)=\frac{E}{1-\nu} \frac{\Delta R}{R}
$$

where $E$ is the Young's modulus and $\nu$ the Poisson ratio. This expression may be oldtained from the general formula for $\sigma_{t}$ versus deptih in a uniform thermoelastic sphere [Solomon and Chaikin, 1976]. Solomon [1986] makes clear, however, that (6) is much more general, applying to the ontermost layer of a planet, considered as an elastic sliell, regardless of the properties of the intcrior. This generality is important because a nuiform elastic sphere is a poor model lor a differentiating Moon. The appropriate model is a rclalively thin elastic sliell surrounding an effectively Huid region, i.e., a balloon [Niven. 1972]. In the deep interior, the temperal.nre is at or near the solidus, allowing relaxation of elaslic stresses by creep. Nearer the surface, stresses are relieved by the opening of fractures and intrusion of magma. Only the outermost region can be treated as elastic, but this is sulficient for the usual $\pm 1 \mathrm{~km}$ limit on ractius variation to obtain. The Moon difters from the usual kind of balloon in one iuportant way, however. Its interior, though effectively fluid (zero shear modulus) is no more compressible than the extcrior. 'The restraining effect of the elastic shell on the expansion of its conlents may therefore be neglected to a good approximation, as was implicitly done in (5).

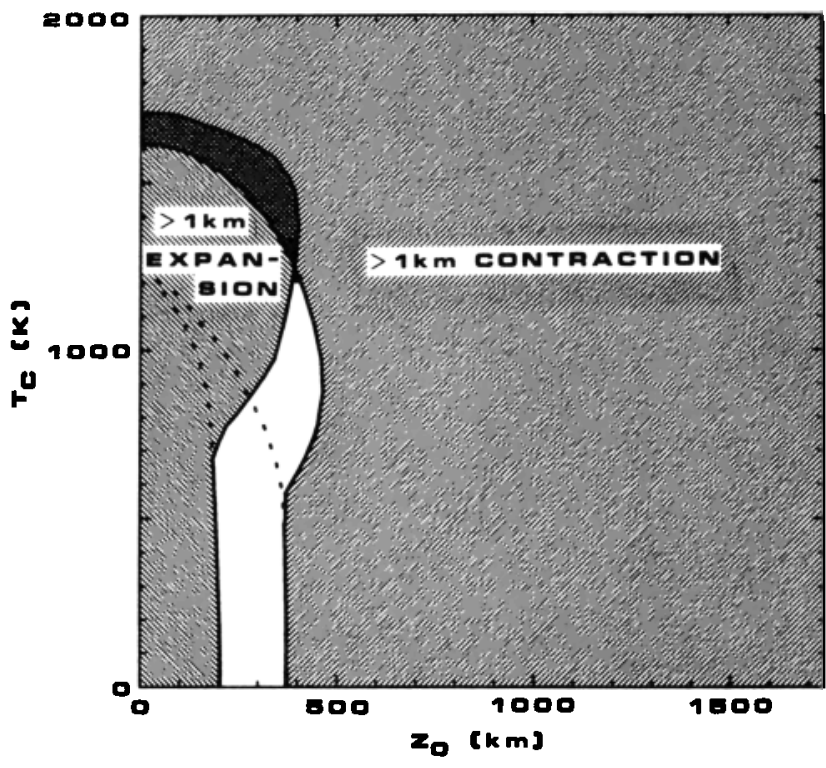

Fig. 2. I, ,mar l herual evolut iun models with 20 ppl bulk utanium cont ent. Sluarlod regions of parametes space are in violalion of the 1- km linit. on expansion or conteraction (or lot.lı) since $3.8 \mathrm{Cryr}$ ago. Dotilel contours imclicale apparent stales of $\pm 1 \mathrm{~km}$ radius rhang if the effect of differentiation is unglected. Dot indicates a mocliel with rentral $1 \mathrm{~cm}$ erature $l_{c}=1210 \mathrm{li}$, and magma ocean depll, $Z_{0}=400 \mathrm{~km}$, which apprars in Figures 3-5.

In aclition to applying the radius constraint, we compare the present-clay surface heat flux to the recent reinterpretation of the Apollo 17 measurement by Warren and Rasmussen [1987]. They modeled the effects of latcral inhomogeneities on thermal conductivity as well as a strongly insulating megaregolith, and concluded that an appropriate globally avcrnged value of the heat finx is probally $1: 2 \mathrm{~m} \mathrm{Wm}^{-2}$. We vary the lunar bulk coutent of uranium (iin alclition to $T_{c}$ and $Z_{0}$ ) to altempt to reproduce this value. Finally, we also keep track of the time of transition (if any) between net expansion and contraction of the Moon. Solomon and Iload [1979) conject.ured that this transition may be responsible for the end of rille and graben formation 3.6 (iypr ago.

Figure 2 summarizes the results of our model calculatious for a bulk uranitum content of $20 \mathrm{ppb}$. The limits on expansion and contraction are simultaneously salisfied for a rauge of models (unshaded region) with $T_{c} \lesssim 1210 \mathrm{~K}$ and $210 \lesssim Z_{0} \lesssim 470 \mathrm{~km}$. The maximum value of $T_{c}$ is aftained for $Z_{0} \simeq 40.5 \mathrm{~km}$. Were one to neglect $\Delta V /\left.V\right|_{d}$, in cont.rast, the maximum acceptable $T_{c}$ would be nearly the same, but the magma ocean would disappear $\left(Z_{0} \rightarrow(1)\right.$ as $T_{c} \rightarrow 1200 \mathrm{~K}$. ()uly for a much colcler core would a $200-400 \mathrm{~km}$ magma ocean be acceplable. This is in kecping with the results of Solomon and Chaikin [1976], whose model resenbles ours but wit.lu 30 pplo of uranium aud a less insulaing crust.

'The present-elay heal flux at the surface is $11.8 \mathrm{~mW} \mathrm{~m}^{-2}$ for our hot,test acceptable model in Fignre 2, falling off to $\sim 8 \mathrm{~m} \mathrm{WV} \mathrm{m}^{-2}$ for the coldest models shown. This is in agreenuenl. with Harren and Masmussen [1987], who calculated the present-elay flux with a very different treatment of lhe lunar interior and arrived at a uraninu content of 2021 pph. If we seek to match Pullan and Lamberk's [1980] temperalure of $973 \mathrm{~K}$ at $240 \mathrm{l}-\mathrm{km}$ dept.J rat.her than the heat 


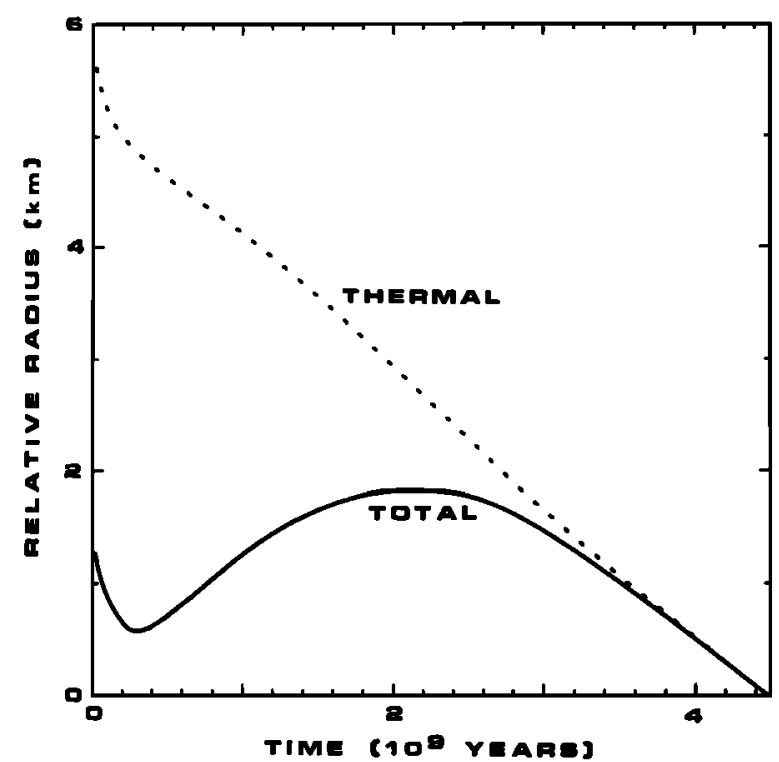

Fig. 3. Relation rarlius of the Noon versus time for the thermal evolution morlel inclicalerl by a dot in Figure 2. Solid curve shows met raclius clasuge, inclurling expansion due lo differentiation, relative Io present ray. Dotied curve shows cont ribution due to thremal comtraction.

flow, we call do so lor $14 \mathrm{pph}$ uranium, $T_{c}=1522 \mathrm{k}$, and $Z_{0}=160 \mathrm{~km}$. This is the same uranium content for which Warren and Rasmussen [1987] satisfied the 240-km lemperalure const mint, and it is the hollest. model will l.his uranium conl('nt that las an acceph albe raclius history.

We will examiue more closely a siugle thermal history calculated with an uranium abundance of $20 \mathrm{ppb}, T_{c}=1210 \mathrm{~K}$ and $Z_{0}=400 \mathrm{~km}$, inclicated by the dot. in Fig. 2. Figure 3 (solicl curve) shows the evolution of the lunar radius with

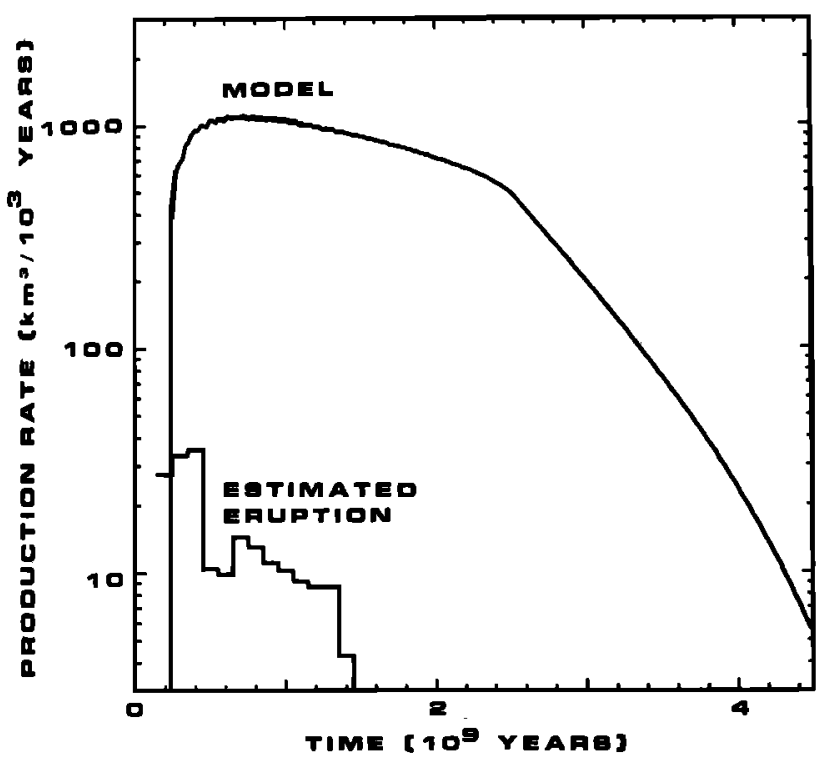

fiig. I. Rat es of Jasaltic melt produrtion. Upper curve shows theorricul melling rate for the morlel inclirated by dot in Figure 2. Break in slope at $\sim 2$ (iyr is rlue to the front at whirh melling begins reanhing the center of the body. Lower rurve shows eslimale of volcunic pruption rale baserl on unit thicknesses and crat er densily ages [ $B V S P, 1981]$. Overall ratio of melt formation to ertuplion is $\sim 98: 1$.

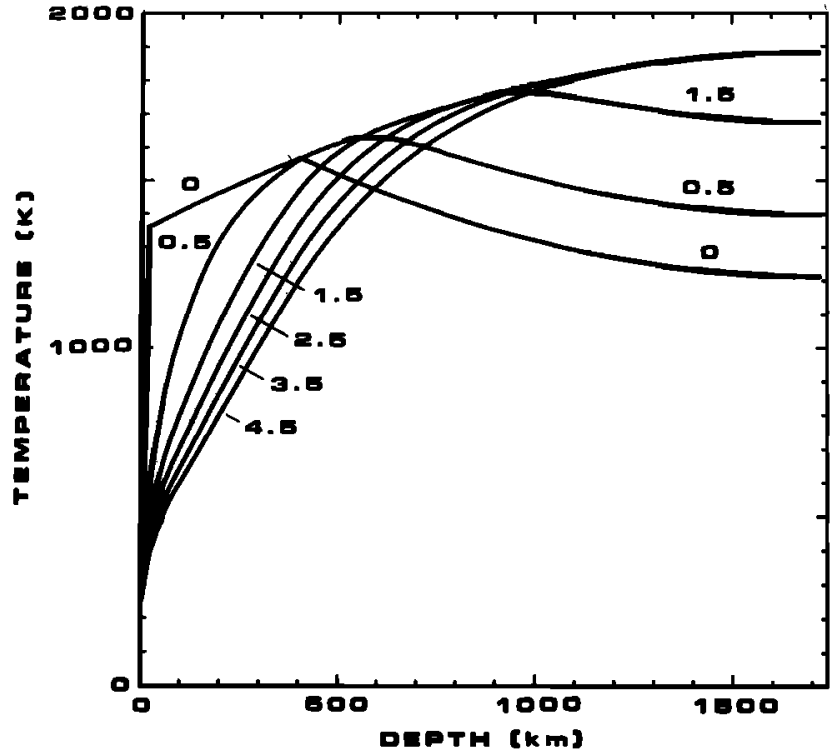

Fig. 5. Rrepresentative selenot herms for the mortel inrlicaterl by lort in Figure 2. Temperalure versus depth is inclicaled for limes of $0.0 .5,1.5,2.5,3.5$, and $1.5 \mathrm{Gyr}$ after formalion. C'urves are boumlerl above by the assumed lasalt solidus (quadratic in dep(l, $)$. Surface heat llux al present is $11.8 \mathrm{~mW} \mathrm{~m}-2$.

lime. As expected for this near-limiting case. the Mloon has been lollh $\sim 1 \mathrm{~km}$ larger and $\sim \mathrm{I} \mathrm{km}$ smaller since 3.8 (igr ago than jts size at that time. For purposes of comparisoll, the dotted curve shows the radius variation for the same thermal history but ignoring $\Delta V /\left.V\right|_{d}$. A monotonic clecrease of nearly $1.5 \mathrm{~km}$ in the last 3.8 (1yr is erroneonsly prediclecl. Note that the maximnm lunar taclins (including differentiation ellecls) occured 2.3 (iyr ago. 'T'his is a gencral feal.nre of our models: as $Z_{0}$ is clecreased, there is an abrupt. transilion from monotonically decreasing raclins historics to oncs with a relatively recent maximum. To push the time of this maximum back to 3.6 (iyy ago requires a central tentperalure in excess of $\sim 15(1) k$, which is not consistent with the const.raiut on the maguilude of $\Delta R$.

'The inst antancons rale of melt generation is slown in Figure 4, along wit.l nu eslimate of the rates of eruption based on thicknesses and ages of major volcanic unils [BVSP. 1981]. 'The ratio of mell production to effusion is as low as $30: 1$ in the early, "upland" llooding stage, and about 101): 1 during the flooding of the maria. Roughly two thirds of the total melting predicted by the model occurs before 1.he end of major mare volcanism $\sim 3$ (tyr ago (a fact disguised somewhat by the logarithmic scale of Figure 4). The rate of melting continnes to decline slowly until about 2 Gyr ago when the onset-of-melting front reaches the center of the Moon, then [alls ofl more rapiclly. 'This is comparable to Ilie ages est.mated from crater densities for the youngest mare basalis [HVSP, 1981]. Overall ahout 98 limes as much mell forms in our model as is believed to have been evolved onto the surlace. 'This is remarkably similar to the rough estimale made in the previous section.

Pinally, in Figure 5 we present selenotherms al. sevcral limes during the evolution of our hothest noolel (solid (urves). The assumed basalt solidus is indicated by the dislied curve, most.ly hidden by the envelope of the selenotherms. Partial melting occurs at all depths greater 
1.han $Z_{0}$ over the conrse of time. About $60 \%$ of the maximmm possible anount of basalt is ext.racted from most parts of the corc, dropping to zero al its top, where cooling is rapicl. Becanse of the density difference between primordial mantle and residumm, this siluation is gravitalionally mustable, and the core will probahly overlurn [Hood, 1986] and achieve a Iniform state of roughly $5.1 \%$ complete basalt ex/raction. 'l'he S'P density of such a mixture of primordial and residnal material is roughly $3350-3450 \mathrm{~kg} \mathrm{~m}^{-3}$ (dependiug on the compositional models chosen). It may be the case, as Taylor [1982] lias objected, that basaltic material would be clenser than is consistent with observations if it existed in the lower mantle of the Moon. 'The same is not true for the residum from which hasalı lias been extracted. Our STP density is simila.s to or sliglit.ly less than typical lower-mantle clensities derivedl [rom geophysical models [Hood and Jones, 1987].

Mclt is still boing formed brlow abont $1300 \mathrm{~km}$. This is consistent with (lliongh not retuired by) the possible increase in seismic shear wave atienuation below $1100 \mathrm{~km}$. Onr present-elay selcnotherm is generally consistent wit.h estimales of lomperature in the lunar interior based on clectrical conductivity and lit.hospheric rigidity. 'These thermal imelicators are discussod ai. length hy Hood [1986].

The thermal and volumetric evolution model presented in this section is far liom definitive. Its primary assets are simplicity and similarity to models from which conclusions abont the Moon's initial thermal state have been clrawn in t.he past. Much refincment in the trentinent of the differentiation process is possible, e.g., calculation of the pressureand temperat.ure-depenclent. volume change on a point-loypoint hasis, using a more realistic mineral scheme, and proper treatment of mass, energy, and racliogenic element, transport hy the melt plase. It is not likely, however, that. these improvements would change the result substanlially. 'l'he possible ynalitalive ellect of subsolidus convection on the t.lucrmal and differcutialion history is of greater interest at this point. Existing convective lunar thermal models [Toksizz ef al., Jits; ('assen et al., 1979] show that horizontally areraged temperatiures can reach the solidus and manlle-wide partial me: ing can occnr. Further melting will bo possible in the upwelling regions even alter the average temperature has clroppecl below the solidus. Whether the extent and liming of melting can be marle consjstent with a ncar-constant. radius history remains to be seen. It is possible that sulssoliclus convection may aclually help, in the sense l hat. more efficient heat. transport will increase the initial tomperalures needed to achieve a given amount of melting. We reitcrale our earlier point, however, 1.liat existing convection calculations cannot be adapted to our purpose because they omit the effects of irreversible differentiation, whiclt are large in our case.

\section{Discussion}

Discussion. Both our scaling estimates based on the magnitude of $\Delta V /\left.V\right|_{d}$ and the particular thermal evolution model we have chosen to investigate suggest that the observed lack of lunar tectonism may be reconciled with an

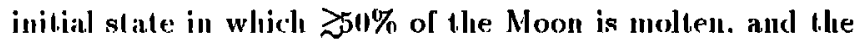
rest within a few hundred Kelvin of the solichs temperal.ure. 'I'his is just one of many possible ontcomes; we have not chosen to meet the challenge of constructing a "definitive" thermal and compositional history of the Moon. Indeed, we conbl. that this cliallenge can be mel at present. However, the simple estimates of the trade-oft between compositional and thermal eflects on volume are in general confiumed by detailed (allecit imperfect) models, in support of our view l.hal a hot eatly Moon cantuot be disconnted. Two issues maturally arise from this conclusion: Why is the volume of mare basalts so small, and how can we reconcile our picture of a parlially molicn early Moon with the initial complcte melling of lunar source malcrial in a giant impact scenario?

We assert that our conclusion of $\sim 10: 1$ intrusive (gal,bro) to extrusive (basalt) igneous activity is not at all unreasonable. While it is true that the ratio of intrusive to extrusive igneons activity in continental regions of the Earth is only $\sim 10: 1$ [Crisp, 1984], it is more pertinent that basalt is not. buoyant or hardy buoyant when ascending near-surlace conduils on the Moon [Walker and Hays, 1977; Bottinga and IVeill, 197(1). An analysis of melt migration along cracks reveals that the local clensity contrast is very important to the alilily of melt, to migrate upward [Stevenson, 1982; Spence et. al.. 1987] (bul see Crawford and Stevenson, [1987] for a potential counterexample), so the ability of basalt to reach the surlace of the Mloon is not. aided hy increasing the depth of the sonce region. One conld legitimately adopt the view that it is remarkable that the Noon has any mare basalls! Conceivahly. iumpact played a role in aiding their exuption.

'llic problem of lunar origin by giant impact requires more work [cl. Stcrenson. 1987]. but it is possible that this scenario is consistent with an initial Moon that is only partially molicn ancl perhaps even subsoliclus at clepth. A. C. 'T'hompson ancl I). J. Stevenson, (Gravilational instability of twophase disks and the origin of the Moon, submitted to As(rophysical Journal, 1987) find that the impact- generated fluid disk unay cool at the periphery, while generating a large IInmber (10)-10 $\left.10^{2}\right)$ of protomoons. These bodies event.nally collicle to form the Moon as we know it, bnt sufficient time elapses for eaxd protomoon lo grow a chill crust. If lhese crusls ruphiure and founder, then a substantial fraction (potentially more than half) of the molten sonce material can freeze before accilmulation. We can place an upper bound on the freezing as follows: Suppose there are $N$ protomoons, each radialing at a temperature $T_{e}$ for a lime $r$. The fraction $x$ of malerial that freczes is then given by

$$
\begin{aligned}
x L M & =4 \pi r_{p}^{2} \sigma T_{e}^{4} \tau \cdot N \\
& =4 \pi R^{2} \sigma_{e}^{\prime} I_{e}^{4} \tau \cdot N^{\frac{1}{3}}
\end{aligned}
$$

where $L$ is the latent. heat. of frezing, $M$ is the mass of the Moon, $R$ is t.he lunar ralius, $r_{p} \simeq N^{-1 / 3} R$ is the protomoon radius, and $\sigma$ is the Stefan-Boltzmann constant. We find

$$
x \simeq 7\left(\frac{T_{e}}{10^{3} \mathrm{~K}}\right)^{4}\left(\frac{\tau}{10^{3} \mathrm{yr}}\right)
$$

Since an arcumulation lime $\tau \simeq 11^{3} \mathrm{yr}$ or more is likely, $x$ can be substautial even if $T_{e}$ is reduced because only a fraction of the surface of a protomoon is molten at any instant. 'The newly formed Moon may consist of a central "core" of clense clitl crust, surrounded by a magma ocean. These icleas are speculative but meril, more work.

We conclnde by remarking that even with the possibilit.y that. cliflerentiation effects may parlially cancel thermal cont raclion, it is astonishing that the Moon exhibits so lit.le evidence for volume cliange. One should be wary of explanalions that. rely on fort nitons cancellation (a criticism that applies ecunally to the old thermal models and to our model). 
Perlonss 1.Jere is more to this puzzle than anyone has yel discortued.

Acknowledgements.'The work presentel here was supporterl by NASA grant NACW-185. Division of Cieologiral and Planetary Sciences, C'alifornia lnstil ule of 'Techuology contribution 1529.

\section{REFERENCES}

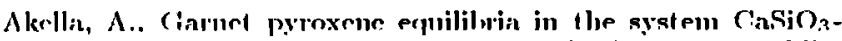
MgSi( $)_{3}-\mathrm{Al}_{2}()_{3}$ ntil in a natural mineral nixime, Am. Mineral. $61,589-598,1976$.

Basalt ic Volcanism St udy Project. Basalt ic Volcanism on the Terresitrial l'lanets, 1286 pp., Pejganom, New York, 1981.

Bruz. W., W. L. Slatlery, and A. (A. W. Cameron, The origin rif thr Moon and the single-impact hypothesis, 1, Icarus, 66, $515-535,1986$.

Benz. W., W. L. Slattery. and A. (i. W. Cameron. The origin of the Mnon and the single-impact hypolhesis, II, Icarus, TI. 30 45.1987.

Bincler. A. B., The first few hundred years of evolution of a Moon "f lission origin, Proc. Lunar Planet. Sci. Conf., 11h, 1931193 !), 1980.

Binrlrer. A. B., Post-Inbrian lunar tectonism: Evidence for an initially totally multen Moon, Moon Planets. 26, $117-1: 33,1982$.

Hincler, A. B., 'The inilial themual state of the Moum. iu Origin of the Moon. edilod l,y W. K. Hartmann, lR. J. Phillips. aud (1. J. 'laylur, 125-434, Lunar' and Flanetary Instilute, Houston, 'Tex., 1 !186.

Bindre. $\Lambda$. B., and M. A. Lange, On the thernal hist ory, thermal state, ancl related tectonism of a Mloon of fission origin, $J$ (ieoplyys. Res., 85. 3194-3208, 1980.

Bol.tinga. Y., and I). F. Weill. Wensities of licpuicl silicate systems calrulated frou pattial molar volumes of oxide componenls, Am. J. Sci.. 269. $169-182.1970$.

Burk, W. R., and M. N. 'Toksöz, The bulk romposilion of the Moon liased on geopliysical coust raints, Proc. Lumar Planet. Sri. Conf. Gith. 20.1:3-2058, 1980.

Caturion, $\Lambda$. ( $i$. W., Jormalion of the prelumar acciolion risk (alst rat), in Papers Presented lo the Conference on the ()rigin of the Moom. p. 58, Lumar and Planetary lnst it ule, Houston, liex., 19884.

C'anmolu, A. (i. W., and W. R. Warr, The origin of the Moon (alsel.ac:(). Lmar Sci.. I11. 120-122, 1976.

('issen, I'., K. 'T. Meynolds, l'. (iraziani. A. Sumumers, .l. McNellis, and I. Blalork, Convertion and Jumar thermal history, Phy's. findh Planet. Inter., 19. 183-196, 1979.

Crawford. (4. D), and D. J. Slevenson, Gas-driven water volcanism and the resuffaring of Europa, lcarts. 73, 6(3-8\%, 1988.

('risp, J. A.. liates of magma emplaremenl and volcanic output, J. Volcanol. Geotherm. Res., 20, 177-211, 1984.

Delajo, J. W., Alundance of Ni, Cr, Co, and majoj elements in IJe silicate portion of the Moon: C'onstraints from primary linial magmas (alsstracl), in Papers Presented to the Conference on the Origin of the Moon, p. 15, Lunar and Planetary Instilule, Houst ou, 'Jex., I984.

(ioins, N. R., The interual structure of the Moon, I'h.D. Thesis, Mass. Inst. of 'reclnol., Cambridge, 1978 .

(irrel, I). H., aut A. H. Ringwoorl, The stability field of alumiunus pyroxche periclotile and garnel peridotite and their relevalle in lpper mantle structure, Earth Planet. Sci. Lett., 3, I5I laio, ISkT.

(irern. D. Il., and A. F. Ringwoor, Signifirance of a primitive luunr lsasaltir composition present in A.pullo 15 soils and brecrias. Warth IVanet. Sci. Isett., 18. 1 -8, 1973.

(irem. 1). H., N. (i. Ware, W. O. Jlibberson, and A. MInjor, Exprrimental petrolngy of Apollo 12 basalts, I, Sample 12009, Earth Planet. Sci. Lett.. 13, 85-96, 1971.

IIn'tmanנ, W. K., and D. R. Davis, Salcllite-sized planetesimals anrl Lumar origin, Icarus. 24. 504-515, 1975.

llearl. .J. W., lunar mare deposits: Areas, volumes, secpuence, and inplication for melling in somre areas (alsst ract), in Papris Presented to the Conference on Origins of Mare Basalts and Their Implications for Lumar Evolution. 66-69, Lumar and Planetary lust itute, Huiston, 'lex., 1975.

Ilooul, I. I., ('ienpliysical constraints on the lumar interior, in Ori- gin of the Moon, edited by W. K. Hartmann, R. J. Phillips, and G. J. Thylnr, 361-410, Lunar and Planet ary Institute, Houston, Tex., 1986.

Howel, L. I., and I. IH. Jones, Geoplyysical const mainls on hunar bulk composition anel structure: A reassessment, Proc. Lunar Planet. Sci. Conf., 17th, J. Geophys. Res. 1, 92, suppl., E396FA11. 1987 .

I,augsedh, M. G., Jr., S. P. C'Iark, Jr., J. L. C'hute, .Jr., S. J. Kejhun, and $A$. P. Wesrliler, 'The Apollo 15 lunar heal-flow measuremwit. Mloon, 4. 340-410, 1972.

Mlan'l)(nald, (1. J. F., Sl.ress listory of the Moon, Planet. Space Sci., 2, 2.19--255, 1960.

Mac(iregor. I. D, The reaction 4 rustalite + spinel $\rightleftharpoons$ forsterite + pvonpe, Year Book Carnegie lisst. Mash., 6.3. 157, 1964.

Mar(iregor. I. I), Stability fields of spiuel anrl gartuet peridol ites in lle synthelic system $\mathrm{MgO}-\mathrm{CaO}_{-} \mathrm{Al}_{2} \mathrm{O}_{3}-\mathrm{SiO}_{2}$, lear Book ('arnegie Inat. Wash., 61. 126-1:34, 1965.

Mar(irrgor. I. l)., 'The eftert of $\mathrm{CaO},\left(\mathrm{r}_{2} \mathrm{O}_{3}, \mathrm{Fe}_{2} \mathrm{O}_{3}\right.$, and $\mathrm{Al}_{2} \mathrm{O}_{3}$ un the staljility of spiuel and garnet periclotites, Phys. Earth r'anet. Inter., 3, 372-377, 1970.

Moggai,. J. W., J. Hertogen, and E. Auders, Tlye Moon: comprisition delrmuined by nebular processes, Moon Planets, 18 , $4105-478.1978$.

Nakimuma. Y., Seismic velority structure of the lunar mant le, $J$. (ieophys. Res.. 88. B7t-68ti. 1983.

Niven, I)., The Moon's a Balloon, 380 pp., G. P. Putnall, New loik, $1 ! 1 \% 2$.

O'Keefe, J. A., Origin of the Moon, J. Geophys. Res., 75. 6565657.1. 1969.

Oxburgh, Li. R., and E. M. Parmentier, C'ompositional and density stratification in oceanic lithosplneje-Cinses anrl consequicices, J. cieol. Soc. Loudon, 133. 343-355, 1977.

Jerkiıs III, I)., 'T. J. B. Holland, and R. C. Newton, The $\mathrm{Al}_{2} \mathrm{O}_{3}$ contents of enstatite in equilibriun with garnet in the systrili $\mathrm{MgO}-\mathrm{Al}_{2}()_{3}-\mathrm{SjO}_{2}$ at $15-40 \mathrm{kbal}$ and $900-1600^{\circ} \mathrm{C}$, Con(rib. Ninemal. Pelfol., 78, $99-100,1981$.

Jullau, S., aurl K. Lamberk, On constraining lunar mantle tiemprontue frum gravity dala, Proc. Lumar Planet. Sci. C'onf., 111h, $2013120111,1080$.

llingwour, A. L., Origin of the Earth and Moon, 295 pp., Springri-Verlag, New York, 1979.

Ruitrorn, S. K., Farly melting of the Moon, Proc. Lunar Sci. r'onf., 8th. 4ti:3-467, 1975.

Schatz, J. I*, and (i. Simmons. Thermal condurtivity of Farth

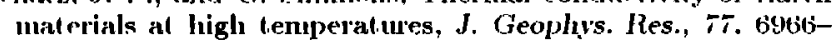
(i.18:3, 1972.

Sillulsert. (A., R. F. Voung, and P. Cassen, Sulssulidus convertion morlels of the litiar interior lemperat ure, Philos. Trans. $R$. Soc. Londoll, Ser. A. 285, 523-536. 1975.

Sr.lulurt, (1., D. Stevenson, and P. Cassen, Whole planel cooling and the rarlingenic heat source cont ents of the Earth and Moou, J. Geophys. Hes.. 85. 25.31 -25.38, 1980.

Skitner, B. J., Thermal expansion of ten minerals, U.S. Geol. Siurv. Prof. Pap. 4.50I), 109-1 12, 1962.

Solomon. S. (!., The rolationslup l,et ween crust al tectonics anrl inIrrnal evolution in the Moon and Mercury, Phys. Earth Planet. Inter.. 15. 135-145, $197 \%$.

Solomon, S. C., On lhe early thermal state of the Mloon, in Origin of the Moon. edited by W. K. Ilartmann. R. .J. Phillips, and G. J. Taỵlor, 435-452, Isunar and Planelary Instit ute, Houston, Trex.. 1986.

Solumw, S. C!.. and .I. C'lıaikin, Thermal expansinu and thernal stress in the Munn nurl terrestrial planets: C'lues to parly lliriual listary. Proc. Lunar Sci. C'onf.. Tth. 3229-3243. 1976.

Solomot, S. C., and J. W. Ilearl, Vertical movement in mare hasius: Ircalion to mare enuplacencul, basin tectonics, and lumar therual history, J. Feophys. Res., 84. 16157-1682, 1979.

Solonum, S. C., and .1. Lungli, Magma oceanogiaplıy, 1, Thernal evolulion, Proc. Lmar Ści. (:onf., 8th, 583-59!), 1977.

Solonou, S. C'., and M. N. 'Tuksöz. Intemal constitution and evolution of the Mloon, Plyvs. Earth Planet. Inter., 7, 15-38, 1973.

Spmice. D. A., P. W. Sharp, and D. L. Turcotte, Buoyancy riven rauk propagation: $\Lambda$ merlanianu for nagna migjalion, J. Fluid Mrch.. 171. 1:35-15:3, 1987.

Stcvenson. D. J., Volcanism and igneous processes in small icy satellites, Natwe. 298. 142-144, 1982. 


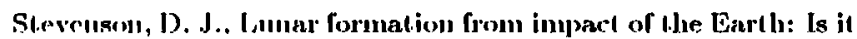
pussil,e? (alsst mar. ). in Papers Presented to the Conference on the (Mrigin of the Mhon, p. 60, Lumar and Planetary Institute, Ilunstom, 'Trx., 1984.

Stcrmson. I). J., Origin of the Monn-The collision hypolhesis, Anmu. Rev. Farth Planet. Sci., 15. 271-315, 1987.

Taỵlou, S. H., Panctary Scicnce: $A$ Immar Perspective, 481 pp., I, mar and I'lanct.uy Institute, Hutuslon, 'lex., 1982.

Thumpsun, $\Lambda$. ('., andi D). J. Stevenson, 'Two-phase ginvitational instal,ilitos in thin rlisks with application to the origin of the Mloon (alsstrae't), lmar Planet. Sci.. XIV, 787-788, 1983.

Ioksïz. M. N., aurl S. C. Solomon, ']'hemnal history and evolution af lle Mloun. Moon. $7.251-278,1973$.

Tiksöz, M. N.. A. 'I'. Ilsui, and [). II. Jolunston. Themual evoluliuns of the lerrestrial planets, Moon Planets, 18, 281-320, 1978.

Tozer. 1). C'., The Mann's llormal state and an interpretation of the Junar electrical conductivity distribution, Moon, 5, 90-105, 19172.

Walker, D., and J. F. Hays, Plagiorlase Hotation and lumar crust. formulion, Feolog. 5. 125-428, 1477.
W'̈̈uke, H.. H. Badrlenlıausen, K. Blun, M. Cenclales, G. Dreibus, II. Ilufmristar, H. Kruse, H. Jagoutz, C. Palme, B. Speltel, R. 'luneker, and Ja. Vilesek, On the chemist ry of lumar samples and arhondriles: I'rinary matter in the lumar lighlands: A re-evaluation. Proc. Lmnar Sci. Conf.. 8th. 21 !)]-221:3, 1977.

Warren, P. H., ancl K. L. Rasmussen, Megaregolith insulation, intornal I amperat ures, and bulk uranimm content of the Moon, J. Gooplus. Hes., 92, 3.153-3465, 1987.

Wise. 1). II., Origin of the Moon from the Farth: Some new merlıanisms and comparisons, J. Geophys. Res., 74, 6031-6045, 1909.

IR. I. liirk. Brancli of Astrogeology, U.S. Geological Survey, 2255 Nortl (temini Drive, Flagstaff, AZ 86001.

1). J. Sirvouson, Division of Geolugical and Planetary Sciences, C'alifor'uia linstitute of 'Technology, Pasadena, CA 91125.

(Iteceived Septemulser 18, 1987; vevisend Julle 20, 1988; accepled July 8, 1988.) 